\title{
Prediction of pregnancy success rate through in vitro fertilization based on maternal age
}

\author{
Soegiharto Soebijanto
}

Department of Obstetrics and Gynecology, Faculty of Medicine, University of Indonesia, Jakarta

\begin{abstract}
Abstrak
Tujuan Untuk mempelajari korelasi antara keberhasilan kehamilan teknik fertilisasi in vitro dengan umur istri.

Metode Dilakukan penilaian kehamilan pada 8 pusat pelayanan fertilisasi in vitro di Indonesia: Rumah Sakit Anak dan Bersalin Harapan Kita sejak tahun 1997 sampai 2001, dan 7 pusat pelayanan fertilisasi in vitro di Indonesia. Induksi folikel dilakukan dengan long protocol, short protocol dan natural cycle. Inseminasi dilakukan di cawan petri dengan cara ICSI (intra cytoplasmic sperm injection). Pengambilan spermatozoa dilakukan dengan masturbasi, biopsi testis dan biopsi epididimis. Keberhasilan kehamilan dinilai dengan kehamilan kimiawi, adanya denyut jantung janin dan kelahiran bayi hidup (take home baby).
\end{abstract}

Hasil Diperoleh hasil kehamilan 34\% untuk kelompok umur dibawah 30 tahun, 33,75\% untuk kelompok umur 31 sampai 35 tahun, 26\% untuk kelompok umur 36 sampai 40 tahun dan 8\% untuk kelompok umur diatas 40 tahun.

Kesimpulan Semakin tinggi usia istri, semakin rendah tingkat kehamilan. Dengan kata lain, semakin tinggi usia istri, semakin tinggi tingkat keguguran. (Med J Indones 2009; 18: 244-8)

\begin{abstract}
Aim To evaluate the correlation between the success of pregnancy through in vitro fertilization and maternal age.

Methods Assessment of pregnancy was performed in eight in vitro fertilization centers in Indonesia: Harapan Kita Pediatric and Obstetric Hospital from 1997 to 2001, and seven in vitro fertilization centers in Indonesia. Follicular induction was performed through the long protocol, short protocol and natural cycle. Insemination was performed through ICSI (intra cytoplasmic sperm injection) on petri dish. Spermatozoa were obtained through masturbation, testicular biopsy and epididimical biopsy. A successful pregnancy was indicated chemically, with the presence of fetal heart beat and the birth of a baby (take home baby).
\end{abstract}

Results There was a 34\% pregnancy rate for the age group below 30 years, 33.75\% for those between 31 and 35 years olds, and $26 \%$ for the age group 36 to 40 years old, and $8 \%$ for the age group above 40 years.

Conclusion The higher the maternal age, the lower pregnancy rate. In other words, the higher the maternal age, the higher the rate of miscarriage. (Med J Indones 2009; 18: 244-8)

Key words: pregnancy, in vitro fertilization

Infertility is the inability of a couple to produce an offspring after on year marriage and regular intercourse without contraception. Based on the cause of the infertility there are various options of therapy aimed at achieving a successful pregnancy. In mild causes therapy may be simple, but with a more severe cause, therapy can be very complex and costly with special preparations. In vitro fertilization or Assisted Reproductive Technology (ART) may help in achieving a successful pregnancy in those who have severe abnormalities, although it does require a strict and lengthy selection and preparation process. ${ }^{1}$

To prepare the patient before undergoing ART, several assessments must be made: duration of marriage, cause of infertility, previous examinations and therapies, previous attempts at pregnancy, and last but not least, maternal age. ${ }^{2}$ The unavailability of ART information throughout society has caused delays of visits for many couples, meaning that the wive would already be too old by the time they come to the comprehensive reproduction clinic.

The ideal age to get pregnant is $20-30$ years old. The deceleration of the ability to get pregnant occurs at the age of 35 . For women 40 years old or older the possibility of pregnancy decreases $50 \%$ each year and by the time they are 45 years old, that possibility becomes zero. ${ }^{3}$

All this is due to the oocyte factor. At a later age, meiotic abnormalities will produce abnormal oocytes. The number of oocytes will be reduced, the quality decreased, fertilization and number of embryos 
lowered. ${ }^{3,4}$ Many studies have shown that 40 years is the maximum age to be a candidate for ART. ${ }^{5,6}$ This age limit still provides the possibility of pregnancy through the sperm donor program and through spontaneous pregnancy. ${ }^{6-8}$ Multiple regression analysis of various factors showed a $17 \%$ rate of successful viable pregnancy per cycle at 30 years of age, decreasing into $7 \%$ at 40 years old and $2 \%$ at 45 years old. ${ }^{9}$ Although age is an important predictive factor, chronological age seems to be an inadequate predictor for ovarian age. ${ }^{10}$ In a study of women who responded negatively to stimulation, USG revealed that the number of antral follicles were lower than those of control subjects. ${ }^{11}$

This study was aimed to evaluate the correlation between the success of pregnancy through in vitro fertilization and maternal age.

\section{METHODS}

Research data was taken from 1987 to 2007 in the Harapan Kita Children and Obstetric Hospital, from 2006 to 2008, at Yasmin Clinic Faculty of Medicine University of Indonesia Cipto Mangunkusumo Hospital and from 2007 to 2008 from six other in vitro fertilization centers (Aster, Hasan Sadikin Hospital, Bandung; Halim Fertility Center, Medan; Morula, Bunda Hospital, Jakarta; Teratai, Gading Pluit Hospital, Jakarta, Family, Family Pluit Hospital, West Jakarta; Graha Amerta, Sardjito Hospital, Yogyakarta) in Indonesia.

Datacollection wasperformed retrospectively. Refferences were retrieved from books and articles through the internet. Results of this study were presented in a main table and percentages were calculated.

Requirements for enrollment in ART were: 1) has undergone basic examinations related to infertility, 2) sufficient understanding of the information related to procedures and therapies in ART, 3) agree to obey the procedures, 4) able to cover the costs of the ART process.

Some indications of ART are: 1) blockage of both fallopian tubes, 2) severe oligospermia, 3) unexplained infertility, 4) stage III/ IV endometriosis (AFS), 5) previous failed of conventional therapies.

On the $2^{\text {nd }}$ day of menstruation, transvaginal ultrasonography was performed to assess the condition of the uterus (measurments of length, width, and thickness), and scanning for benign tumors (myoma). If any tumors were detected, we recorded the number, size and location. We also assessed the ovaries, its sizes, and the number of basal follicles (basal anthral follicles) and categorize according to the number of basal follicles such as: hyporesponder if there are less than 5 follicles, normoresponder if there are 5 to 15 follicles, and hyperresponder if there are more than 15 follicles. The number of basal follicles represent the ovarian reserve and is very useful in predicting the fertility of a woman. The next procedure was to take blood samples to see the concentration of the basic profile hormones that includes FSH (Follicle Stimulating Hormone), LH (Luteinizing Hormone), PRL (Prolactin), and E2 (Estradiol).

During the $8^{\text {th }}$ to $12^{\text {th }}$ day of menstruation we performed HSG (Hysterosalphingography) to assess the cavity of the uterus and both fallopian tubes. During the $18^{\text {th }}$ to $20^{\text {th }}$ day of menstruation we performed an embryo transfer rehearsal using the Frydman catheter (the catheter that will be used during the actual embryo transfer) and also an assessment of the cavity of the uterus and the direction from which the catheter will enter the uterus.

We performed sperm analysis at least twice to find out the quality of sperm and its fluctuations. Examinations were performed between 3 to 5 days interval after sperm release and then another sperm release at the laboratory to obtain a complete analysis.

The methods of therapy were categorized into three groups according to each couple's conditions. They are:

\section{Long Protocol Group}

Therapy was initiated with the administration of Buserelin starting at day 21, continuously for two weeks. After that a USG (ultrasonography) was performed and a basic hormonal profile was obtained. When the requirements were met, Buserelin was continued with the addition of hormonal injections containing recombinant FSH in a dose customized to the patient's response. Patients were asked to come twice a day: at 8 am for USG to monitor the development of follicle and to obtain blood samples to determine the consentration of the Estradiol hormone. During the day the patient was asked to come at $1 \mathrm{pm}$ to receive a recombinant FSH injection in a customized dose according to the follicular development and the concentration of Estradiol, until the average follicular diameter was 20 $\mathrm{mm}$ and the average concentration of Estradiol was 200 $\mathrm{pg} / \mathrm{ml}$. When achieved, Buserelin was then discontinued and the patient was asked to come at $8 \mathrm{pm}$ to receive a 
hCG injection of $10.000 \mathrm{IU}$ intramuscularly to achieve oocyte maturation.

After 34 hours, we performed ovum pick up guided by USG. One hour later the husband was asked to give sperm that will be rinsed in medium solution. When ejaculate does not contain spermatozoa, sperm was obtained from the testicle or epididimis. From here we were able to obtain spermatozoa with adequate morphology to be inseminated into the oocyte.

For couples who provided good quality of sperm $(>20$ million $/ \mathrm{ml}$ ), one oocyte was introduced to 100.000 spermatozoa in a petri dish. The specimen was then incubated for 2-5 days. After that, we selected the specimen with the best conception result based on the morphology and cleavage. Only qualified embryos will be transferred into the uterus.

Every four days after that the patient received luteal phase support: injection of $1500 \mathrm{IU}$ hCG intramuscularly, a total of two injections. After that we performed a measurement of the Estradiol and Progesteron concentration to monitor if the developing embryo. Confirmation of pregnancy was done 14 days after embro transfer by testing morning urine, if the result was positive then the patient was confirmed pregnant biochemically. Clinical pregnancy was established after 2 weeks later through USG with the appearance of a gestational sac and fetal pole. Four weeks later the fetus will appear morphologically intact complete with a heart beat.

\section{Short Protocol}

This method of therapy takes as long as the normal menstrual cycle \pm 28 days. The short protocol is basically similar to the long protocol, the difference lies in the administration of the substance that triggers follicular maturation (FSH), given starting the second day of menstruation through subcutaneous injection in the abdominal area with a customized dose based on the patient's every day condition, added with the administration of $0.25 \mathrm{mg}$ of GnRH (gonadotropine releasing hormone) antagonist, subcutaneously, starting from the $7^{\text {th }}$ day for five consecutive days until the average follicular diameter was $18 \mathrm{~mm}$.

\section{Natural Cycle Protocol}

This therapy method follows the patient's menstrual cycle, in average between 21 to 28 days. Starting from the second day, we performed an evaluation of the internal reproductive organs and the basal hormonal concentration (FSH, LH, E2, PRL), subsequently on the $6^{\text {th }}, 9^{\text {th }}$, and $11^{\text {th }}$ day we performed a measurement of the E2 concentration and the average diameter of the follicles. If it has reached a diameter of $14 \mathrm{~mm}$ and the E2 concentration was more than $100 \mathrm{pg} / \mathrm{ml}$, then the hCG injection was given within 34 hours prior to ovum pick up (OPU). Data are presented descriptively as number and percentage

\section{RESULTS}

Table 1 shows the results of RSAB Harapan Kita within a period of 1987-2001, in the less than 30 years old-group there were 460 cycles that had undergone embryo transfer and a clinical pregnancy was achieved for 137 couples $(33 \%)$. In the age group of 31 to 35 years old there were 1012 cycles, 855 of those received a successful embryo transfer (84\%). In the age group of 36-40 years old, there were 981 cycles, $6 \%$ did not fulfill requirements to commence to OPU, $756(77 \%)$ received embryo transfer, and 165 (19\%) achieved pregnancy. Of the above 40 age group there were 145 cycles, 25 cycles were cancelled, 85 embryos were transferred, and 12 couples achieved pregnancy.

This shows that the biggest age group to join the ART program was 31-40 years old. This is because the younger age group was composed of couples who had just gotten married, and thus were undergoing simpler treatments. After all has failed at the age of 31, then they visit the ART clinic

Table 1. Success of ART in Melati RSAB, 1987- 2007.12

\begin{tabular}{ccccccccc} 
Age & \multicolumn{3}{c}{ CycleIVF } & \multicolumn{3}{c}{ Cancelled Embryo transfer } & \multicolumn{2}{c}{ Pregnant } \\
\hline$\leq 30$ & 460 & $(18 \%)$ & 9 & $(2 \%)$ & 414 & $(90 \%)$ & 137 & $(33 \%)$ \\
$31-35$ & 1012 & $(39 \%)$ & 44 & $(4 \%)$ & 855 & $(84 \%)$ & 265 & $(30 \%)$ \\
$36-40$ & 981 & $(38 \%)$ & 63 & $(6 \%)$ & 756 & $(77 \%)$ & 165 & $(19 \%)$ \\
$>40$ & 145 & $(6 \%)$ & 25 & $(17 \%)$ & 108 & $(59 \%)$ & 12 & $(8 \%)$ \\
\hline
\end{tabular}

The two percent cancellation occured in the age group below 30 years, $4 \%$ in the $31-35$ year age group, $6 \%$ in the $36-40$ year age group, and $17 \%$ in the above 40 age group. From here it is obvious that the older the age, the higher the rate of cancellation due to inadequate response to stimulation of the ovaries.

From the embryo transfers we can see that $90 \%$ of transfer cycles occur in the below 30 age group, $84 \%$ 
in the $31-35$ age group, $77 \%$ in the $36-40$ age group, and $59 \%$ in the above 40 age group. This reveals that the older the patient the higher the cancellation rate of embryo transfer, due to the inadequate quality of the embryos. This was due to inadequate oocyte quality due to aging of the oocytes remaining in the ovaries.

\section{Results from the Yasmin Clinic 2004-2008}

In the 20-25 age group we obtained an average of 8.4 oocytes, 9.7 oocytes in the 26-30 age group, 7.2 occytes in the 31.35 age group, 5 in the 36-40 age group, and 4 in the above 40 age group. This proves that ovarian aging occurs even after standar stimulation was performed.

Table 2. Number of patients, oocytes, and pregnancy according to age in the Yasmin IVF center 2006-2008

\begin{tabular}{cccccc}
\hline Age & $20-25$ & $26-30$ & $31-35$ & $36-40$ & $>40$ \\
\hline Patients & 9 & 20 & 61 & 53 & 18 \\
Oocytes & 76 & 194 & 476 & 270 & 74 \\
Average oocytes & 8,4 & 9,7 & 7,2 & 5 & 4 \\
Embryo & 51 & 94 & 258 & 139 & 41 \\
Average embryos & 6 & 5 & 4 & 3 & 2 \\
Pregnant & 3 & 8 & 17 & 13 & 1 \\
\% Pregnant & $30 \%$ & $40 \%$ & $27,8 \%$ & $24,6 \%$ & $5,5 \%$ \\
\hline
\end{tabular}

This is also in accordance to the average of obtained embryos declining as the patient gets older: 6 in the 2530 age group, 5 in the 26-30 age group, 4 in the 31-35 age group, 3 in the 36-40 age group and 2 in the above 40 age group. The rate of pregnancy also declined as the age increases, drastically so in the above 40 age group.

This shows that age is a major consideration for those above 40 , considering the pregnancy rate is only $5.5 \%$. Other parameters need to be calculated in deciding to go on with this costly treatment, such as hormonal parameters.

\section{Results from 6 other ART centers in Indonesia}

Table 3 shows the results of 8 ART centers in Indonesia. Similar to the results from Yasmin Clinic and RSAB Harapan Kita, we found that the rate of pregnancy declined according to the increase in age. A drastic decline was observed in the 38 to 40 age group. But then, in contrast to the results from the Yasmin Clinic and RSAB Harapan Kita, the results did not decline drastically in the 41-42 age group. This shows that the patient's age can not be the only factor deciding the course of treatment for each couple. Other parameters may still be explored to determine if treatment may be commenced.

Table 3. The number of cycles and percentage of pregnancy in the 6 ART centers in Indonesia

\begin{tabular}{lcccccc}
\hline & \multicolumn{5}{c}{ Pregnancy in age group } \\
\hline ART center & Cycles & $<35$ & $35-37$ & $38-40$ & $41-42$ & $43-45$ \\
6 ART center & 708 & 38 & 38 & 28 & 20 & 6 \\
\hline
\end{tabular}

\section{DISCUSSION}

As we know, the fertility rate is influenced by many factors, among them, maternal age. The ovaries are among the few organs that have a dual function: as reproductive organs that produce oocytes, and as hormonal organs that create hormones playing roles in reproduction as well as feminine functions. These two functions do not remain for life but have a limited effective period that can not be prolonged. The ovaries age faster than the general physical condition.

Our observations revealed that couples who sign up for ART in the age $\leq 35$ years have a greater chance at pregnancy achievment (39.28\%), and the least chance for miscarriage (18.8\%) compared to the age group .3540 years old. This gives the impression that the quality of the oocyte and steroidal hormones are still adequate to achieve a higher rate of pregnancy and a lower rate of miscarriage.

We conclude that the overall rate of success among the couples undergoing ART was 29.46\% (clinical pregnancy/ET). This is far from the patient's expectations who think that undergoing the ART would increase their chances of pregnancy significantly, or even guarantee it. The success rate is relatively high, considering that if not for the ART they had a zero chance of pregnancy. The rate of success in ART is influenced by many factors that a couple may not comprehend, such as: sperm quality, the presence of ovarian cyst, myoma, reproductive hormonal balance, and couple's age especially the wive's.

From the data we collected it seems that one of the key factors that determine the success of ART is wive's age, and this we deduce from the fact that the older the patient, the lower the rate of success. In the $\leq 35$ year old age group the rate of pregnancy was quite high (39.28\%) compared to the $35-40$ age group who had $27.86 \%$ and the $>40$ age group who had $21.73 \%$. the success of pregnancy was also 
followed with a higher rate of miscarriage in the $>40$ age group (60\%), compared to the $>35-40$ age group $(23.5 \%)$ and the $\leq 35$ age group (18.18\%).

It is concluded that the older the patients the lower the rate of pregnancy or the higher the chance of miscarriage.

\section{Acknowledgment}

We thanks the team at ART Aster, RS Hasan Sadikin, Bandung; Halim Fertility Center, Medan; Morula, RS Bunda, Jakarta; Melati, RSAB Harapan Kita Jakarta; Teratai, RS Gading Pluit Jakarta, Yasmin, Makmal/ RSCM; Family, RS Family Pluit Jakarta Barat; Graha Amerta, RS Sardjito Yogyakarta

\section{REFERENCES}

1. Piette C, de Mouzon J, Bachelot A, Spira A. In-vitro fertilization: influence of women's age on pregnancy rates. Hum Reprod. 1990; 5:56-9

2. Tucker MJ, Morton PC, Wright G, Ingargiola PE, Jones AE, Sweitzer CL. Factors affecting success with intracytoplasmic sperm injection. Reprod Fertil Dev. 1995; 7:229-36

3. Ashkenazi J, Orvieto R, Gold-Deutch R, Feldberg D, Dicker D, Voliovitch I, Ben Rafael Z. The impact of woman's age and sperm parameters on fertilization rates in IVF cycles. Eur J Obstet Gynecol Reprod Biol. 1996; 66:155-9

4. Hull MG, Fleming CF, Hughes AO, McDermott A. The age-related decline in female fecundity: a quantitative controlled study of implanting capacity and survival of individual embryos after in vitro fertilization. Fertil Steril. 1996; 65:783-90

5. Widra EA, Gindoff PR, Smotrich DB, Stillman RJ. Achieving multiple-order embryo transfer identifies women over 40 years of age with improved in vitro fertilization outcome. Fertil Steril. 1996; 65:103-8

6. Templeton A, Morris JK, Parslow W. Factors that affect outcome of in-vitro fertilisation treatment. Lancet. 1996; 348:1402-06

7. Legro RS, Shackleford DP, Moessner JM, Gnatuk CL, Dodson WC. ART in women 40 and over. Is the cost worth it? J Reprod Med. 1997; 42:76-82

8. te Velde ER, Pearson PL. The variability of female reproductive ageing. Hum Reprod Update. 2002; 8:141-54

9. van Hooff MH, Alberda AT, Huisman GJ, Zeilmaker GH, Leerentveld RA. Doubling the human menopausal gonadotrophin dose in the course of an in-vitro fertilization treatment cycle in low responders: a randomized study. Hum Reprod. 1993; 8:369-73

10. Tarlatzis BC, Zepiridis L, Grimbizis G, Bontis J. Clinical management of low ovarian response to stimulation for IVF: a systematic review. Hum Reprod Update. 2003; 9:61-76

11. Faber BM, Mayer J, Cox B, Jones D, Toner JP, Oehninger S, Muasher SJ. Cessation of gonadotropin-releasing hormone agonist therapy combined with high-dose gonadotropin stimulation yields favorable pregnancy results in low responders. Fertil Steril. 1998; 69:826-30

12. Muchsin J, Yuslam EF, Hadi S, Muharam, Soegiharto S: 20 tahun Pengalaman Pelayanan Program Bayi Tabung di Indonesia: Memperingati 20 tahun Program Bayi Tabung di Indonesia. Seminar Awam Perkembangan Mutakhir Penanganan Medis Masalah Ingin Anak. Jakarta, Mei 2008 